\title{
METABOLIČKI SINDROM KOD BOLESNIKA SA HRONIČNOM OPSTRUKTIVNOM BOLEŠĆU PLUĆA: UČESTALOST I POVEZANOST SA KLINIČKIM KARAKTERISTIKAMA
}

\author{
METABOLIC SYNDROME IN PATIENTS WITH CHRONIC OBSTRUCTIVE PULMONARY \\ DISEASE: FREQUENCY AND RELATIONSHIP WITH CLINICAL CHARACTERISTICS
}

\section{Tatjana Vujić, Gorica Marić, Ljudmila Nagorni Obradović, Snežana Cvetković}

\begin{abstract}
SAŽETAK: Uvod: Metabolički sindrom (MetS) je čest kod bolesnika sa hroničnom opstruktivnom bolešću pluća (HOBP). Sistemska inflamacija igra važnu ulogu i u HOBP i u MetS-u. Cilj studije je bio da se proceni učestalost MetS-a kod bolesnika sa HOBP i da se evaluišu razlike između bolesnika sa HOBP i MetS-om i bolesnika sa HOBP bez MetS-a u odnosu na demografske i kliničke karakteristike kao i stepen inflamacije.

Metode: Studija preseka je obuhvatila 115 bolesnika sa stabilnom HOBP. MetS je definisan prema kriterijumima Međunarodne federacije za dijabetes. Kod svih bolesnika su određene komponente MetS-a $i$ C-reaktivni protein (CRP), učinjena je spirometrija. Klasifikacija HOBP je načinjena prema kriterijumima Globalne inicijative za hroničnu opstruktivnu bolest pluća- GOLD.

Rezultati: MetS je prisutan kod 35,65\% bolesnika sa HOBP. Učestalost MetS-a kod bolesnika u GOLD stadijumima I, II, III, IV je bila 50,0\%; 44,9\%; 29,3\%; 17,6\% (redom). Nije bilo razlika između bolesnika sa HOBP i MetS-om i bolesnika sa HOBP bez MetS-a u odnosu na starost, pušenje i dužinu HOBP. Bolesnici sa HOBP i MetS-om su pokazali značajno viši nivo CRP-a.

Zaključak: studija pokazuje da je MetS čest kod bolesnika sa HOBP. Nivo CRP-a je značajno viši kod bolesnika sa HOBP koji imaju MetS nego kod bolesnika sa HOBP bez MetS-a. Ovi nalazi sugerišu da je potreban skrining bolesnika sa HOBP za pridruženi MetS i povišene markere inflamacije, $u$ cilju kontrolisanja ovih komponenti $i$ posledičnog smanjenja rizika od kardiovaskularnog morbiditeta $i$ mortaliteta kod ovih bolesnika.
\end{abstract}

Ključne reči: Hronična opstruktivna bolest pluća, Metabolički sindrom, C-reaktivni protein

\section{Uvod}

Hronična opstruktivna bolest pluća (HOBP) je kompleksna i progresivna bolest koja je odgovorna za značajan morbiditet i mortalitet širom sveta. HOBP primarno karakterišu opstrukcija protoku vazduha u disajnim putevima i inflamacija na nivou pluća, ali značajna obeležja su i sistemska inflamacija i ekstrapulmonalni efekti. Sistemske manifestacije i komorbiditeti, među kojima su kardiovaskularne bolesti (KVB) i dijabetes tip 2, imaju visoku prevalenciju u bolesnika sa HOBP i značajno utiču na simptome i zdravstveno stanje ovih bolesnika. KVB i dijabetes se registruju u svim stadijumima HOBP i povećavaju rizik za hospitalizaciju i mortalitet ${ }^{1,2}$.
Pretpostavlja se da sistemska inflamacija predstavlja osnovni patogenetski mehanizam koji povezuje HOBP i komorbiditete. Smatra se da nastaje "prelivanjem" inflamatornog procesa i inflamatornih medijatora iz pluća u sistemsku cirkulaciju ("spill over" hipoteza) ${ }^{3}$. Navode se i drugi faktori kao što su duvanski dim, hipoksija, preces starenja. Postojanje i intenzitet sistemske inflamacije kod bolesnika sa HOBP se mogu proceniti određivanjem nivoa inflamacijskih medijatora $\mathrm{u}$ cirkulaciji: citokina, hemokina, reaktanata akutne faze ( $\mathrm{C}$ reaktivni protein- $\mathrm{CRP}$ i dr) ${ }^{4,5}$.

Metabolički sindrom (MetS) predstavlja skup metaboličkih poremećaja (centralna gojaznost, hiperglikemija, hipertenzija i dislipidemija: povišeni trigliceridi i snižen high density lipoprotein- HDL 
holesterol) koji povećavaju rizik za nastanak KVB i dijabetesa tipa $2^{6}$.

Prevalencija metaboličkog sindroma u bolesnika sa HOBP, prema različitim istraživanjima, iznosi $21-58 \%$ i veća je nego u opštoj populaciji. Faktori koji su odgovorni za učestalu pojavu MetS u bolesnika sa HOBP su: gojaznost, smanjena fizička aktivnost, pušenje, primena kortikosteroida, inflamacija, oksidativni stres, hipoksija. Kod bolesnika sa HOBP istovremeno postojanje metaboličkog sindroma je povezano sa povećanim mortalitetom (MetS predisponira razvoj KVB koje značajno povećavaju rizik od smrtnog ishoda) ${ }^{7}$.

Procena metaboličkog statusa, kao i nivoa cirkulišućih inflamatornih markera može da doprinese celovitijem sagledavanju bolesnika sa HOBP, kao i boljem planiranju preventivnih i terapijskih intrevencija.

Cilj ovog rada je da se ispita učestalost metaboličkog sindroma kod bolesnika sa HOBP i da se istraže razlike između bolesnika sa HOBP koji imaju MetS i bolesnika sa HOBP bez MetS u pogledu demografskih i kliničkih karakteristika, kao i pokazatelja sistemske inflamacije.

\section{Metode}

Studijom preseka je obuhvaćeno 115 bolesnika sa HOBP u stabilnoj fazi koji su lečeni u Klinici za pulmologiju Kliničkog centra Srbije, u periodu mart 2015- januar 2016. godine i koji su ispunjavali kriterijume za uključivanje $u$ istraživanje. Ispitivanje je odobreno od strane Etičkog komiteta Medicinskog fakulteta Univerziteta u Beogradu i svi učesnici su potpisali informisani pristanak. Kriterijumi za uključivanje u studiju: dijagnoza HOPB (prema preporukama Globalne inicijative za hroničnu opstruktivnu bolest pluća -GOLD ${ }^{2}$ ), starost preko 18 godina i stabilna faza bolesti (bez egzacerbacije najmanje šest nedelja pre ispitivanja). Kriterijumi za isključenje iz studije: primena sistemskih kortikosteroida u periodu od šest nedelja pre ispitivanja, akutna infekcija (respiratornog $\mathrm{i}$ drugih organskih sistema), druge inflamatorne bolesti (kolagene vaskularne bolesti, inflamatorne bolesti creva), druge bolesti respiratornog sistema, postojanje maligne bolesti, odbijanje učešća u studiji.
Dijagnoza metaboličkog sindroma je postavljena prema kriterijumima Međunarodne federacije za dijabetes (International Diabetes Federation- IDF):

- obim struka $\geq 94 \mathrm{~cm}$ kod muškaraca ili $\geq 80$ $\mathrm{cm}$ kod žena plus bilo koja dva od sledećih kriterijuma:

- glukoza našte $\geq 5,6 \mathrm{mmol} / \mathrm{L}$ ili prethodno dijagnostikovan tip 2 dijabetesa

- trigliceridi $\geq 1,7 \mathrm{mmol} / \mathrm{L}$ ili primena specifičnih lekova

- HDL (high density lipoprotein- lipoprotein visoke gustine) holesterol $<1,03 \mathrm{mmol} / \mathrm{L}$ kod muškaraca ili $<1,29 \mathrm{mmol} / \mathrm{L}$ kod žena ili primena specifičnih lekova

- sistolni krvni pritisak $\geq 130 \mathrm{~mm} \mathrm{Hg} \mathrm{i/ili}$ dijastoli krvni pritisak $\geq 85 \mathrm{~mm} \mathrm{Hg}$ ili lečenje prethodno dijagnostikovane hipertenzije ${ }^{8}$.

Kod svih ispitanika su učinjene sledeće procedure:

- anamneza i klinički pregled

- prikupljanje demografskih i kliničkih podataka pomoću specijalno dizajniranog upitnika: pol, starost, pušački status (pušač, bivši pušač: prestao sa pušenjem $\geq 1$ godine, nepušač) i intenzitet pušenja (paklo/godina: godine pušenja $\mathrm{x}$ broj dnevno popušenih cigareta/20), dužina trajanja HOBP (od momenta postavljanja dijagnoze).

- standardna spirometrija (spirometarMasterscreen Pneumo,Viasys Healthcare) je sprovedena prema preporukama Evropskog respiratornog udruženja ${ }^{9}$. Određeni su: forsirani vitalni kapacitet (FVC), forsirani ekspiratorni volumen u prvoj sekundi $\left(\mathrm{FEV}_{1}\right)$ $\mathrm{i}$ odnos $\mathrm{FEV}_{1} / \mathrm{FVC}$. Klasifikacija HOBP je učinjena prema GOLD kriterijumima (spirometrijska klasifikacija težine HOBP bazirana na post-bronhodilatatornom $\mathrm{FEV}_{1}$ )stadijum I (blaga): $\mathrm{FEV}_{1} / \mathrm{FVC}<0.70 ; \mathrm{FEV}_{1} \geq$ $80 \%$ predviđenog; stadijum II (umerena): $\mathrm{FEV}_{1} / \mathrm{FVC}<0.70 ; 50 \% \leq \mathrm{FEV}_{1}<80 \%$ predviđenog; stadijum III (teška): $\mathrm{FEV}_{1} / \mathrm{FVC}$ $<0.70 ; 30 \% \leq \mathrm{FEV}_{1}<50 \%$ predviđenog; stadijum IV (veoma teška): $\mathrm{FEV}_{1} / \mathrm{FVC}<$ $0.70 ; \mathrm{FEV}_{1}<30 \%$ predviđenog ${ }^{2}$.

- telesna visina i težina su merene u lakoj odeći i bez obuće, a indeks telesne mase (body mass index- BMI) je računat deljenjem težine sa kvadratom visine $\left(\mathrm{kg} / \mathrm{m}^{2}\right)$. 
- obim struka je meren pomoću neelastične trake na srednjoj liniji između najnižeg rebra i ilijačne kriste.

- krvni pritisak je meren sfigmomanometrom (Omron MX3 Plus,Omron, Japan) prema preporukama American Hearth Association ${ }^{10}$.

- laboratorijske analize: uzorak venske krvi je uziman nakon 12 sati gladovanja.

Glikemija, trigiceridi i HDL holesterol su određivani enzimskim metodama, a C- reaktivni protein imunoturbidimetrijskom metodom (analizator Beckman Coulter).

\section{Statistička analiza}

Podaci su prikazani kao srednja vrednost sa standardnom devijacijom (SD) za kontinuirana obeležja, odnosno kao apsolutne vrednosti i procenti za kategorijska obeležja.

Razlike između grupa su ispitivane primenom Studentovog $\mathrm{t}$ testa za kontinuirana obeležja i Chikvadrat testa za kategorijska obeležja. U svim analizama vrednost $\mathrm{p}<0,05$ je smatrana statistički značajnom.

Statistička analiza je sprovedena upotrebom softverskog paketa SPSS, verzija 17.

\section{Rezultati}

Istraživanjem je obuhvaćeno 115 bolesnika sa HOBP.

Prosečna starost ispitanika je iznosila $63.9 \pm 8.9$ godina; od ukupnog broja bolesnika $62,6 \%$ su muškarci, a 37,4\% žene.

Među ispitanicima je bilo 46,1\% aktivnih pušača, $53,9 \%$ bivših pušača, dok nepušača nije bilo. Intenzitet pušenja prikazan indeksom paklo/godine je iznosio prosečno 48,19 $\pm 28,75$.

Prosečan BMI je iznosio $26,54 \pm 5,86 \mathrm{~kg} / \mathrm{m}^{2}$.

Srednja vrednost $\mathrm{FEV}_{1}(\%$ predviđenog $)$ je 48.88 $\pm 20,22$.

Najveći broj bolesnika pripada GOLD II stadijumu $49(42,6 \%)$ i GOLD III stadijumu 41 $(35,7 \%)$, a znatno manji broj GOLD IV stadijumu $17(14,7 \%)$ i GOLD I stadijumu 8 (7,0\%).

Bolest je prosečno trajala (od momenta postavljanja dijagnoze) $6,6 \pm 5,2$ godine.

Prosečna vrednost serumskog CRP- a je iznosila $4,18 \pm 3,12 \mathrm{mg} / \mathrm{L}$.
Karakteristike bolesnika sa HOBP su date na Tabeli 1.

Tabela 1: Karakteristike bolesnika sa hroničnom opstruktivnom bolešću pluća

\begin{tabular}{|l|c|}
\hline Obeležje & Srednja vrednost (SD) \\
\hline Starost (god) & $63,9(8,98)$ \\
\hline Pol & $72(62,6)^{*}$ \\
Muškarci & $43(37,4)^{*}$ \\
Žene & $26,54(5,86)$ \\
\hline BMI (kg/m2) & $53(46,1)^{*}$ \\
\hline Pušački status & $62(53,9)^{*}$ \\
Aktivni pušač & $0(0)^{*}$ \\
Bivši pušač & $48,19(28,75)$ \\
Nepušač & $48,88(20,22)$ \\
\hline Paklo/godina & $8(7,0)^{*}$ \\
\hline FEV1, \% predviđenog & $49(42,6)^{*}$ \\
\hline GOLD stadium & $41(35,6)^{*}$ \\
1 & $17(14,8)^{*}$ \\
\hline 2 & $6,63(5,23)$ \\
3 & $4,18(8,46)$ \\
\hline
\end{tabular}

SD - standardna devijacija; * - vrednosti su prikazane kao No (\%); BMI - body mass index (indeks telesne mase); $\mathrm{FEV}_{1}$ - forsirani ekspiratorni volumen u prvoj sekundi; GOLD - Global Initiative for Chronic Obstructive Lung Disease (Globalna inicijativa za hroničnu opstruktivnu bolest pluća); $\mathrm{CRP}-\mathrm{C}$ reaktivni protein

Metabolički sindrom je dijagnostikovan kod $35,65 \%$ (41/115) bolesnika sa HOBP.

Najveći procenat bolesnika sa MetS je registrovan u GOLD I stadijumu: 50\% (4/8), zatim u GOLD II stadijumu: 44,9\% (22/49), sledi GOLD III stadijum: $29,3 \%(12 / 41)$ i GOLD IV stadijum: $17,6 \%(3 / 17)$.

Ukoliko se analiziraju pojedinačne komponenate metaboličkog sundroma prema kriterijumima IDF-a, može se zapaziti da među ispitivanim bolesnicima sa HOBP, $74,8 \%$ ima povećan obim struka, a $36,5 \%$ ima povišene vrednosti glukoze. Kod 16,5\% bolesnika se registruju povišeni trigliceridi, a kod 13,9\% snižen HDL holesterol. Takođe sistolni krvni pritisak je povišen kod 49,6\%, a dijastolni kod $28,7 \%$ bolesnika. (Tabela 2 )

\section{Tabela 2: Komponente metaboličkog sindroma kod} bolesnika sa HOBP

Komponenta MetS-a Srednja vrednost (SD)

\begin{tabular}{|l|c|}
\hline Obim struka $(\mathrm{cm})$ & $97,72(15,10)$ \\
\hline Sistolni pritisak $(\mathrm{mmHg})$ & $127,08(17,71)$ \\
\hline Dijastolni pritisak $(\mathrm{mmHg})$ & $79,30(9,57)$ \\
\hline Trigliceridi $(\mathrm{mmol} / \mathrm{L})$ & $1,30(0,63)$ \\
\hline HDL holesterol $(\mathrm{mmol} / \mathrm{L})$ & $2,99(1,31)$ \\
\hline
\end{tabular}




\begin{tabular}{|l|c|}
\hline Glukoza (mmol/L) & $5,56(1,80)$ \\
\hline Povećan obim struka*, No (\%) & $86(74,78)$ \\
\hline Povišen sistolni pritisak*, No (\%) & $57(49,56)$ \\
\hline Povišen dijastolni pritisak*, No (\%) & $33(28,69)$ \\
\hline Povišeni trigliceridi*, No (\%) & $19(16,52)$ \\
\hline Snižen HDL holesterol*, No (\%) & $16(13,91)$ \\
\hline Povišena glukoza*, No (\%) & $42(36,52)$ \\
\hline Metabolički sindrom, No (\%) & $41(35,65)$ \\
\hline
\end{tabular}

Rezultati su prikazani kao srednja vrednost (SD- standardna devijacija), odnosno No(\%); *: prema kriterijumima IDF (International Diabetes Federation); HOBP: hronična opstruktivna bolest pluća; MetS: metabolički sindrom; HDL: high density lipoprotein (lipoprotein visoke gustine)

Između bolesnika sa HOBP koji su imali metabolički sindrom i bolesnika sa HOBP bez mataboličkog sindroma nije zapažena statistički značajna razlika u pogledu starosti, pušačkog statusa i intenziteta pušenja kao i trajanja HOBP. Bolesnici sa HOBP i MetS su imali značajno veći $\mathrm{FEV}_{1}(\%$ predviđenog) nego bolesnici sa HOBP bez MetS $(\mathrm{p}=0,005)$. Takođe je kod bolesnika sa HOBP koji su imali MetS registrovana značajno viša vrednost CRP- a, nego kod bolesnika sa HOBP bez MetS-a $(\mathrm{p}=0,003)$. (Tabela 3$)$

Tabela 3: Razlike između bolesnika sa HOBP koji imaju MetS i bolesnika sa HOBP bez MetS-a

\begin{tabular}{|l|c|c|c|}
\hline Obeležje & $\begin{array}{c}\text { HOBP bez } \\
\text { MetS }\end{array}$ & $\begin{array}{c}\text { HOBP sa } \\
\text { MetS }\end{array}$ & $p$ \\
\hline Starost (god) & $65,51(9,65)$ & $64,0(8,31)$ & 0,400 \\
\hline $\begin{array}{l}\text { Aktivni pušač, No } \\
(\%)\end{array}$ & $35(47,3)$ & $18(43,9)$ & 0,726 \\
\hline Paklo/godina & $53,03(34,53)$ & $42,90(24,29)$ & 0,099 \\
\hline BMI (kg/m2) & $24,62(5,23)$ & $30,09(5,94)$ & $0,000^{*}$ \\
\hline $\begin{array}{l}\text { FEV1, \% } \\
\text { predviđenog }\end{array}$ & $44,68(18,36)$ & $55,36(20,29)$ & $0,005^{*}$ \\
\hline $\begin{array}{l}\text { Trajanje bolesti } \\
\text { (god) }\end{array}$ & $8,10(6,92)$ & $6,30(4,92)$ & 0,144 \\
\hline CRP (mg/L) & $3,73(2,69)$ & $5,70(4,04)$ & $0,003^{*}$ \\
\hline
\end{tabular}

Rezultati su prikazani kao srednja vrednost (SD- standardna devijacija), odnosno No(\%); HOBP: hronična opstruktivna bolest pluća; MetS: metabolički sindrom; BMI: body mass index (indeks telesne mase); $\mathrm{FEV}_{1}$ : forsirani ekspiratorni volumen u prvoj sekundi; CRP: C reaktivni protein

\section{Diskusija}

Ovo istraživanje je pokazalo da više od $35 \%$ bolesnika sa HOBP ima metabolički sindrom. Zapažaju se značajne varijacije u prevalenciji MetS kod bolesnika sa HOBP u pojedinim istraživanjima i prevalencija se kreće od 21 do 58\%. Prevalencija
MetS kod bolesnika sa HOBP u različitim studijama zavisi značajno od kriterijuma upotrebljenih za postavljanje dijagnoze MetS, kao i od kriterijuma korišćenih za uključivanje bolesnika sa HOBP u studiju. Prevalencija se razlikuje i u zavisnosti od geografskog područja odnosno etničke grupe koja je ispitivana.

Tako je u studiji Wats-a i sar, koja je sprovedena u Nemačkoj, uz upotrebu IDF kriterijuma, prevalencija MetS kod bolesnika sa HOBP iznosila $47,5 \%{ }^{11}$. U studiji Minas-a i sar. ${ }^{12}$ sprovedenoj u Grčkoj, prema kriterijumima ATP III (Adult Treatment Panel III $)^{6}$ uz isključivanje bolesnika sa dijabetesom, poznatim kardiovaskularnim oboljenjem i drugim komorbiditetima, prevalencija MetS-a je iznosila 21\%. Istraživanja sprovedena u Kini (Lam i sar) ${ }^{13}$ i Japanu (Funakoshi i sar) ${ }^{14}$ nalaze da $22,6 \%$, odnosno $23 \%$ bolesnika sa HOBP ima MetS. U studiji Hosny-a i sar. ${ }^{15}$ iz Egipta, MetS je dijagnostikovan kod $40 \%$ bolesnika sa HOBP. Slične prevalencije nalaze $u$ svojim studijama $i$ Akpinar i sar. ${ }^{16}$ iz Turske $(44,6 \%)$ i Diez-Manglano i sar. $^{17}$ iz Španije $(42,9 \%)$. Stanciu i sar. ${ }^{18}$ iz Rumunije pokazuju da 48,1\% bolesnika sa HOBP ima MetS, dok Mekov i sar. ${ }^{19}$ iz Bugarske nalaze relativno nisku prevalenciju od $25 \%$. U studiji sprovedenoj u našoj sredini, u Srbiji, od strane $\breve{S} k r b i c ́ a^{20}$, učestalost MetS-a kod bolesnika sa HOBP iznosi $38,2 \%$. Istraživanje Breyer i sar. ${ }^{21}$ pokazuje višu prevalenciju u odnosu na navedene: 57\%. Takođe istraživanje koje je sproveo Park i sar. ${ }^{22}$ u SAD pokazuje visoku prevalenciju od $58 \%$.

Učestalost metaboličkog sindroma kod bolesnika sa HOBP od 35,65\% u našem istaživanju bi se mogla okarakterisati kao srednja učestalost u odnosu na rezultate napred navedenih studija.

$\mathrm{U}$ istraživanjima je uočena tendencija ređeg javljanja metaboličkog sindroma kod bolesnika sa teškom HOBP. Ovo može biti uslovljeno gubitkom telesne mase što se često viđa kod bolesnika u višim stadijumima HOBP. Brojne studije su pokazale da je MetS češći u ranijim stadijumima HOBP i kod mlađih ispitanika, $\mathrm{i}$ ovi bolesnici bi mogli konstituisati specifični HOBP fenotip. Sledeća istraživanja podržavaju ove navode. Tako u studiji Wats-a i sar. ${ }^{11}$ prevalencija MetS-a u GOLD stadijumima I-IV iznosi redom 50\%, 53\%, 37\% i $44 \%$. Akpinar i sar. ${ }^{16}$ pokazuju sledeću distribuciju MetS-a u GOLD I-IV: 38,5\%; 52,8\%; 30\%; 33,3 \%. U istraživanju Diez-Manglan-a i sar. ${ }^{17}$ svi bolesnici 
su pripadali GOLD II, III, IV stadijumu, a učestalost MetS-a je iznosila redom 51,2\%; 41,2\%; 25,5\%. U studiji koju su sproveli Ozgen Alpaydin i sar. ${ }^{23} \mathrm{u}$ Turskoj prevalencija MetS-a kod bolesnika sa HOBP je iznosila 44\%. Autori su uočili značajnu razliku u prevalenciji MetS-a u različitim GOLD stadijumima: najviša prevalencija je zabeležena u stadijumu II $(59 \%)$, a najniža u stadijumu IV $(4,5 \%)$, i tako su potvrđeni nalazi da je MetS češći u ranim stadijumima HOBP.

Naši nalazi da je metabolički sindrom mnogo češći u GOLD stadijumima I (50\%) i II (44,9\%) nego u stadijumima III $(29,3 \%)$ i IV $(17,6 \%)$ je u saglasnosti sa nalazima napred navedenih studija.

Važan nalaz u ovom istraživanju je da je nivo sistemske inflamacije izražen kroz vrednost cirkulišećeg CRP-a, značajno viši kod bolesnika sa HOBP koji su imali MetS nego kod bolesnika sa HOBP bez MetS-a $(\mathrm{p}=0,003)$.

Wats i sar. ${ }^{11}$ su pokazali da je postojanje MetS-a kod bolesnika sa HOBP povezano sa povišenim nivoom markera sistemske inflamacije. Bolesnici sa HOBP koji su imali MetS su pokazivali značajno više nivoe visoko- senzitivnog CRP-a, kao i interleukina $6 \mathrm{u}$ poređenju sa bolesnicima sa HOBP bez MetS-a. Akpinar i sar ${ }^{16}$, kao i Stanciu i sar. ${ }^{18}$ su u svojim istraživanjima takođe utvrdili povišen nivo CRP- a kod bolesnika sa HOBP i metaboličkim sindromom, pokazujući tako da je kod njih nivo sistemske inflamacije viši nego kod bolesnika sa HOBP bez MetS-a.

Ovo istraživanje ima i izvesna ograničenja: prvo, radi se o studiji preseka, čiji dizajn otežava utvrđivanje uzročno- posledične povezanosti između ispitivanih obeležja. Drugo, istraživanje je rađeno na malom uzorku i u samo jednom centru.

\section{Zaključak}

Ovo istraživanje je pokazalo da je u našoj sredini matabolički sindrom čest kod bolesnika sa HOBP.

Učestalost MetS je veća kod bolesnika sa manje teškom HOBP.

Nivo sistemske inflamacije je značajno viši kod bolesnika sa HOBP koji su imali MetS nego kod bolesnika sa HOBP bez MetS-a.

Nalazi ovog istraživanja pokazuju da prisustvo metaboličkog sindroma kao i nivo markera sistemske inflamacije kod bolesnika sa HOBP treba da budu predmet aktivnog ispitivanja. To će omogućiti da se navedeni faktori blagovremeno stave pod kontrolu, a to ce dalje smanjiti rizik od kardiovaskularnog morbiditeta i mortaliteta kod bolesnika sa HOBP.

\section{LITERATURA}

1. Pauwels RA, Rabe KF. Burden and clinical features of chronic obstructive pulmonary disease (COPD). Lancet. 2004; 364:613-620.

2. Global Initiative for Chronic Obstructive Lung Disease (GOLD). Global Strategy for the Diagnosis, Management and Prevention of Chronic Obstructive Pulmonary Disease. 2017 Report Available on: www.goldcopd.com

3. Barnes PJ, Celli BR. Systemic manifestations and comorbidities of COPD. Eur Respir J. 2009; 33: 1165-1185

4. Agusti AG, Noguera A, Sauleda J, Sala E, Pons J, Busquets X. Systemic effects of chronic obstructive pulmonary disease. Eur Respir J. 2003; 21(2): 347360

5. Gan WQ, Man SF, Senthilselvan A, Sinn DD. Association between chronic obstructive pulmonary disease and systemic inflammation: a systemic review and a metaanalysis. Thorax. 2004; 59;574580

6. Alberti KG, Eckel RH, Grundy SM, Zimmet PZ, Cleeman JI, Donato KA, et al; International Diabetes Federation Task Force on Epidemiology and Prevention; Hational Heart, Lung, and Blood Institute; American Heart Association; World Heart Federation; International Atherosclerosis Society; International Association for the Study of Obesity. Harmonizing the metabolic syndrome: a joint interim statement of the International Diabetes Federation Task Force on Epidemiology and Prevention; National Heart, Lung, and Blood Institute; American Heart Association; World Heart Federation; International Atherosclerosis Society; and International Association for the Study of Obesity. Circulation. 2009; 120: 1640-1645

7. Wells CE, Baker EH. Metabolic syndrome and diabetes mellitus in COPD. Rabe KF, Wedzicha JA, Wouters EFM (eds). COPD and Comorbidity. European Respiratory Society, Sheffield, 2013, 117134.

8. Alberti KG, Zimmer P, Shaw J. Metabolic syndrome- a new world-wide definition. A Consensus Statement from the International Diabetes Federation. Diabet Med.2006; 23: 469-480.

9. Quanjer PH, Tammeling GJ, Cotes JE, Pedersen OF, Peslin R,Yemault JC. Lung volumes and forced 
ventilatory flows. Report Working Party Standardization of Lung Function Tests, European Community for Steel and Coal. Official Statement of the European Respiratory Society. Eur Respir J.1993; Suppl.16:5-40.

10. Pickering TG, Hall JE, Appel LJ, Falkner BE, Graves J, Hill MN, et al. Recommendations for Blood Pressure Measurement in Humans and Experimental Animals. Part1: Blood Pressure Measurement in Humans. A Statement for Professionals From the Subcommittee of Professionals and Public Education of the American Heart Association Council on High Blood Pressure Research. Hypertension. 2005; 45:142-161

11. Watz H, Waschki B, Kirsten A, Muller K, Kretchmar G, Meyer $\mathrm{T}$, et al. The metabolic syndrome in patients with chronic bronchitis and COPD: frequency and associated consequences for systemic inflammation and physical inactivity. Chest. 2009; 136: 1039-1046.

12. Minas M, Kostikas K, Papaioannou AI, Mystridou P, Karetsi E, Georgoulias P, et al. The association of metabolic syndrome with adipose tissue hormones and insulin resistance in patients with COPD without comorbidities. COPD. 2011; 8: 414-420.

13. Lam KBH, Jordan RE, Jiang CQ, Thomas GN, Miller MR, Zhang WS, et al. Airflow obstruction and metabolic syndrome: the Guangzhou Biobank Cohort Study. Eur Respir J.2010; 35: 317-323.

14. Funakoshi Y, Omori H, Mihara S, Marubayashi T, Katoh $\underline{\mathrm{T}}$. Association between airflow obstruction and the metabolic syndrome and its components in Japanese men. Intern Med. 2010; 49: 2093-2099.

15. Hosny H, Abdel-Hafiz H, Moussa H, Soliman A. Metabolic syndrome and systemic inflammation in patients with chronic obstructive pulmonary disease. Egyptian Journal of Chest Diseases and Tuberculosis. 2013; 62: 85-89.
16. Akpinar EE, Akpinar S, Ertek S, Sayin E, Gulhan M. Systemic inflammation and metabolic syndrome in stable COPD patients. Turbek Toraks. 2012; 60, 3: 230-237.

17. Diez-Manglano J, Barquero-Romero J, Almagro P, Cabrera FJ, Garcia FL, Montero L, et al . COPD patients with and without metabolic syndrome: clinical and functional differences. Intern Emerg Med. 2014; 9: 419-425.

18. Stanciu S, Marinescu R, Iordache M, Dumitrescu S, Muresan M, Bogdan MA. Are systemic inflammatory profiles different in patients with COPD and metabolic syndrome as compared to those with COPD alone? Rom J Intern Med. 2009; 47, 4: 381-386.

19. Mekov E, Slavova Y, Tsakova A, Genova M, Kostadinov D, Minchev D, et al . Metabolic syndrome in hospitalized patients with chronic obstructive pulmonary disease. PeerJ. 2015; 3:e1068; DOI 10.7717/peerj.1068.

20. Skrbic D. Metabolic syndrome in patients with chronic obstructive pulmonary disease (dissertation) (Novi Sad): University of Novi Sad. 2015;192 p

21. Breyer M-K, Spruit MA, Hanson CK, Franssen FME, Vanfleteren LEGW, Groenen MTJ, et al. Prevalence of metabolic syndrome in COPD patients and its consequences. PLOS ONE. 2014; 9(6): e98013.

22. Park SK, Larson JL. Metabolic syndrome and associated factors in people with chrobstructive pulmonary disease. West J Nurs Res. 2014; 36 (5): 620-42

23. Ozgen Alpaydin A, Konyar Arslan I, Serter S, Sakar Coskun A, Celik P, Taneli F et al. Metabolic syndrome and carotid intima-media thickness in chronic obstructive pulmonary disease. Multidisciplinary Respiratory Medicine. 2013; 8:61.

Abstract: Introduction: Metabolic syndrome (MetS) is frequent in patients with chronic obstructive pulmonary disease (COPD). Systemic inflammation plays an important role in both COPD and MetS. The aim of the study was to assess the frequency of MetS in COPD patients and to evaluate the differences between COPD patients with MetS and COPD patients without MetS in regard to demographics, clinical characteristics and inflammation.

Methods: The cross sectional study included 115 stable COPD patients. MetS was defined using criteria of the International Diabetes Federation. Components of MetS and $C$-reactive protein (CRP) were measured and spirometry was performed in all patients. The staging of COPD was made according to Global Initiative for Chronic Obstructive Lung Disease- GOLD criteria.

Results: MetS was present in 35.65\% COPD patients. The frequencies of MetS in patients in GOLD stages I, II, III, IV were 50.0\%; 44.9\%; 29.3\%; $17.6 \%$ respectively. There were no differences between COPD patients with MetS and COPD patients without MetS in regard to age, smoking and COPD duration. COPD patients with MetS showed significantly higher CRP level. 
Conclusion: This study shows that MetS is frequent in patients with COPD. CRP level is significantly higher in COPD patients with MetS than in patients without MetS. These findings suggest that physicians should screen COPD patients for associated MetS and for elevated inflammatory markers, in order to control these components and, therefore, reduce the risk of cardiovascular morbidity and mortality in these patients.

Key-words: Chronic obstructive pulmonary disease, Metabolic syndrome, C- reactive protein

Tatjana Vujic,

Klinika za pulmologiju,

Klinički centar Srbije,

Koste Todorovica 26, 11000 Beograd, Srbija;

tel. +381113663491, mob. +381641364074,

e-mail:tvujic@vektor.net 